\title{
Structures and Absolute Configurations of Antibiotics of the Oligosporon Group from the Nematode-trapping Fungus Arthrobotrys oligospora
}

\author{
M. G. ANDERSON, T. B. JARMAn and R. W. Rickards* \\ Research School of Chemistry, Australian National University, \\ Canberra, ACT 0200 Australia
}

(Received for publication December 20, 1994)

\begin{abstract}
Spectroscopic data define the structures of three new antibiotics, $4^{\prime}, 5^{\prime}$-dihydro-oligosporon (4), hydroxyoligosporon (5) and 10',11'-epoxyoligosporon (6) from the nematode-trapping fungus Arthrobotrys oligospora, and confirm the structures of the recently reported antibiotics oligosporon (1) and oligosporol B (3). The absolute configuration of the substituted 7-oxabicyclo[4.1.0]hept-3-ene nucleus of these metabolites is determined by circular dichroic spectroscopy. Oligosporon (1) and its dihydro-derivative (4) represent the second and most complex structural type of nematocidal metabolite to be characterised from cultures of nematophagous fungi.
\end{abstract}

The dramatic ability of a fungal species, Arthrobotrys oligospora, to capture nematodes was first reported by ZoPF in $1888^{1,2)}$ This widely occurring fungus has since been extensively investigated as a model for nematodefungus interactions, ${ }^{3,4)}$ and may have potential in the biological control of nematode parasites of plants ${ }^{5)}$ and animals. ${ }^{6}$ Stadler, STERner and ANKe have recently reported the isolation, structure elucidation and biological activities of oligosporon (1), oligosporol A (2) and oligosporol B (3), novel metabolites from cultures of a strain of $A$. oligospora obtained from the Centraalbureau voor Schimmelcultures, Baarn, The Netherlands. ${ }^{7)}$ The compounds exhibited weak anti- bacterial, antiyeast, cytotoxic and haemolytic effects, but were not active against filamentous fungi or the nematode Caenorhabditis elegans. They represent a new class of natural products, and are the first antimicrobial antibiotics from predacious Deuteromycetes to be described.

In parallel to the German work, we have independently isolated oligosporon (1) and oligosporol B (3) from an Australian isolate of $A$. oligospora and established their structures as (1) and (3). ${ }^{8)}$ Furthermore, our strain yields a number of related antibiotics. We report here the structures of three of these, namely $4^{\prime}, 5^{\prime}$-dihydro-oligosporon (4), hydroxyoligosporon (5) and 10',11'-epoxy-

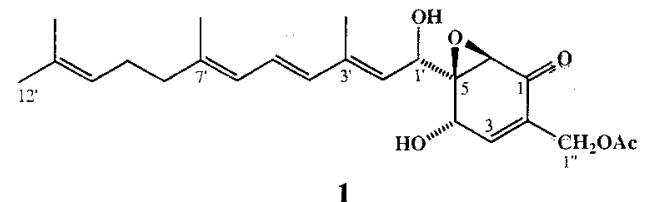<smiles>COC(=O)[C@H]1C=C([OH2+])C2(C(O)/C=C(C)/C=C/C=C(\C)CCC=C(C)C)OC2[C@@H]1O</smiles>

3

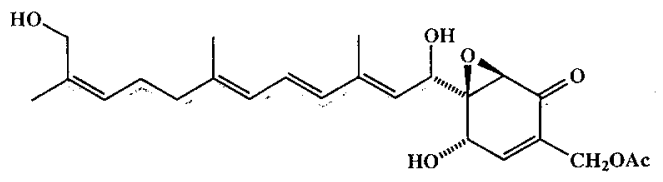

5<smiles>COCC1=C[C@@H](O)C2(C(O)/C=C(C)/C=C/C=C(\C)CCC=C(C)C)OC2C1O</smiles>

2<smiles>CC(=O)OCC1=C[C@H](O)C2(C(O)/C=C(\C)CC/C=C(\C)CCC=C(C)C)OC2C1=O</smiles>

4<smiles>CC(=O)OCC1=C[C@H](O)C23OC2C(=O)C(C(O)C=C(C)C=CC=C(C)CCC2OC2(C)C)=C[C@H]3O1</smiles><smiles>CC(C)=CCC/C(C)=C/CC/C(C)=C/C(O)[C@@]12O[C@@H]1[C@@H](O)C(C(=O)OCc1ccccc1)=C[C@H]2O</smiles> 
oligosporon (6) ${ }^{8)}$ Oligosporol B (3) fractions contain a minor inseparable component which is probably 4',5'-dihydro-oligosporol B (7). We present evidence for the absolute configuration of the substituted 5-hydroxy7-oxabicyclo[4.1.0]hept-3-ene-2-one nucleus of $4^{\prime}, 5^{\prime}$ dihydro-oligosporon (4), and the extrapolation of this configuration to corresponding stereogenic centres in the other metabolites. Results from antimicrobial and nematocidal assays on these metabolites are also described.

\section{Experimental}

General

NMR spectra were recorded for acid-free $\mathrm{CDCl}_{3}$ solutions on Varian Gemini-300 or VXR-500 instruments at 300 or $500 \mathrm{MHz}$ for ${ }^{1} \mathrm{H}$ and 75.43 or $125.75 \mathrm{MHz}$ for ${ }^{13} \mathrm{C}$. The solvent ${ }^{1} \mathrm{H}$ and ${ }^{13} \mathrm{C}$ signals, $7.27 \mathrm{ppm}$ for residual $\mathrm{CHCl}_{3}$ and $77.0 \mathrm{ppm}$ for $\mathrm{CDCl}_{3}$, were used as internal references. Signal assignments are based on direct spectrum analysis, selective proton decoupling, $\mathrm{H}$, H-COSY, APT, HMQC and HMBC data for compounds (1), (4) and (5), and on direct and comparative analysis and APT data for compounds (3) and (6). Small coupling constants were obtained by resolution enhancement of the spectra. EI, HR-EI and CI mass spectra were recorded on a VG Micromass $7070 \mathrm{~F}$ spectrometer, FAB spectra on a VG ZAB2-SEQ spectrometer using 3-nitrobenzyl alcohol as the matrix. UV spectra were recorded on a Hewlett-Packard 8450A spectrophotometer, FTIR spectra on a Perkin-Elmer 1800 spectrophotometer, and CD spectra on a Carey 61 spectrophotometer.

Fermentation and Isolation of Antibiotics

Potato dextrose broth (4 liters, Difco Laboratories, Detroit, U.S.A.) adjusted to $\mathrm{pH} 5.6$ with $2 \mathrm{M}$ sodium hydroxide was inoculated with $A$. oligospora (strain M2, Dr. G. R. STIRLING, Queensland Department of Primary Industries, Indooroopilly, Queensland, Australia) grown on corn meal agar. Fermentation was carried out in $250-\mathrm{ml}$ Erlenmeyer flasks, each containing $100 \mathrm{ml}$ of medium, shaken at $200 \mathrm{rpm}$ at $25^{\circ} \mathrm{C}$ for 7 days. Bioautography of EtOAc extracts of the culture liquor on silica gel TLC (Merck Kieselgel $60 \mathrm{~F}_{254}$ ) in $\mathrm{MeOH}-\mathrm{CHCl}_{3}(1: 9)$ showed two main zones of activity corresponding to quenching of UV fluorescence at $\mathrm{Rf}$ 0.56 and 0.40 . Each zone inhibited the growth of Streptomyces aureofaciens, Pythium ultimum and Phytophthora cinnamomi, whilst the Rf 0.56 zone also inhibited Rhizoctonia solani. The mycelium was removed by filtration, and the filtrate extracted with EtOAc $(3 \times 1$ liter). The combined extracts were dried $\left(\mathrm{Na}_{2} \mathrm{SO}_{4}\right)$ and concentrated in vacuo on a rotary evaporator to a brown oil (400 mg). Extraction of the wet mycelium with stirred $\mathrm{Me}_{2} \mathrm{CO}$ (1 liter), filtration, concentration in vacuo to an aqueous residue, and back extraction with EtOAc
$(3 \times 100 \mathrm{ml})$ afforded after drying $\left(\mathrm{Na}_{2} \mathrm{SO}_{4}\right)$ a darker oil $(1.73 \mathrm{~g})$

The culture filtrate extract, after passage through a short silica gel column in EtOAc, was subjected to gradient elution in EtOAc $-\mathrm{CH}_{2} \mathrm{Cl}_{2}(3: 7$ to $9: 1)$ on a silica gel Chromatotron plate $(2 \mathrm{~mm})$ to give a series of bioactive fractions. Combined fractions 4 and 5 were subjected to reverse phase HPLC on an octadecylsilane column in $\mathrm{MeCN}-\mathrm{H}_{2} \mathrm{O}(3: 1)$ to yield oligosporon (1) (14 mg) and 4',5'-dihydro-oligosporon (4) (4 mg). Further chromatography of combined Chromatotron fractions 6 and 7, and 9 and 10, on Sephadex LH-20 (Pharmacia $\mathrm{LKB}$, Uppsala, Sweden) in $\mathrm{MeOH}-\mathrm{CH}_{2} \mathrm{Cl}_{2}$ (3: 97) gave $10^{\prime}, 11^{\prime}$-epoxyoligosporon (6) (4 mg) and hydroxyoligosporon (5) (14 mg), respectively. Metabolites (1) and (5) were primarily responsible for the zones of activity, observed at Rf 0.56 and 0.40 respectively, on TLC of culture extracts.

The mycelium extract was subjected to similar filtration through silica gel and gradient elution on Chromatotron plates. Combined fractions 7 and 8 were re-chromatographed in EtOAc- $\mathrm{CH}_{2} \mathrm{Cl}_{2}(3: 7)$ on a silica gel Chromatotron plate $(1 \mathrm{~mm})$ to afford a mixture of oligosporon (1) and 4',5'-dihydro-oligosporon (4) (8.9 $\mathrm{mg}$ ). Similar re-chromatography of combined fractions $15 \sim 18$ gave oligosporol B (3) (21 mg), containing a minor component tentatively identified as $4^{\prime}, 5^{\prime}$-dihydro-oligosporol B (7).

\section{Bioassay of the Antibiotics}

Antimicrobial assays were carried out by incorporating into warm agar solutions of the test compounds in $\mathrm{Me}_{2} \mathrm{CO}$, and examining the ability of the resulting agar to inhibit growth of the test organisms from aq. drop (bacteria) or agar plug (fungi) inocula over a period of 48 hours. Nutrient agar (Difco Laboratories, Detroit) was used for bacteria, potato dextrose agar (Oxoid, Basingstoke) for fungi. Nematode larval development assays were carried out by Dr. E. LACEY, McMaster Laboratory, Division of Animal Health, CSIRO, Sydney. ${ }^{9)}$

Physico-chemical Properties of the Antibiotics

$\overline{\mathrm{MS}}, \overline{\mathrm{UV}}, \mathrm{IR}, \mathrm{CD}$, and ${ }^{1} \mathrm{H}$ and ${ }^{13} \overline{\mathrm{C}} \overline{\mathrm{NMR}}$ data for oligosporon (1), 4',5'-dihydro-oligosporon (4), hydroxyoligosporon (5), 10',11'-epoxyoligosporon (6), and oligosporol B (3) are compared in Tables 1, 2 and 3. Data for oligosporon (1) and oligosporol B (3) were in agreement with reported data, ${ }^{7)}$ with the proviso that NMR spectra of the latter showed varying amounts $(10 \sim 30 \%)$ of a second component. This component, provisionally identified as $4^{\prime}, 5^{\prime}$-dihydro-oligosporol B (7), showed a separate ${ }^{1} \mathrm{H}$ NMR signal at $\delta 5.30$ (dq, $J=8.7$, $\left.1,3 \mathrm{~Hz}, \mathrm{H}-2^{\prime}\right)$ and ${ }^{13} \mathrm{C}$ NMR signals at $\delta 121.0\left(\mathrm{C}-2^{\prime}\right), 142.5$ $\left(\mathrm{C}-3^{\prime}\right), 16.1\left(3^{\prime}-\mathrm{Me}\right), 39.7\left(\mathrm{C}-4^{\prime}\right), 26.3\left(\mathrm{C}-5^{\prime}\right), 123.4\left(\mathrm{C}-6^{\prime}\right)$, $135.6\left({\left.\mathrm{C}-7^{\prime}\right),}_{16.0}\left(7^{\prime}-\mathrm{Me}\right), 39.7\left(\mathrm{C}-8^{\prime}\right), 124.2\left(\mathrm{C}-10^{\prime}\right)\right.$. 


\section{Results and Discussion}

Structures of the Antibiotics

All five metabolites were unstable, decomposing on storage even when refrigerated. Mass spectrometry in our hands gave relatively weak molecular ions under EI, $\mathrm{CI}$ and FAB ionisation conditions, in contrast to the results of STADLER and co-workers who report molecular ions with $30 \sim 40 \%$ of the base peak intensity in EI spectra of oligosporon (1) and oligosporols A (2) and B (3). ${ }^{7)}$ Attempts to prepare more volatile derivatives of oligosporon (1) for mass spectrometry failed, methylation with methanolic diazomethane, acetylation with acetic anhydride in pyridine, and trimethylsilylation with bis-(trimethylsilyl)-triffuoroacetamide in the presence of trimethylsilyl chloride all resulting in extensive decomposition. Molecular formulae could, however, be obtained by HR-MS measurements in EI spectra of molecular ions and daughter ions formed by water loss. These data (Table 1) indicated that compounds (3) and (4) were dihydro-derivatives of oligosporon (1), whilst compounds (5) and (6) were mono-oxygenated derivatives. Furthermore, mass measurement of the base peak at $\mathrm{m} / \mathrm{z}$ 69 in EI-MS of oligosporon (1) and oligosporol B (3) established the composition $\mathrm{C}_{5} \mathrm{H}_{9}^{+}$, suggesting the presence of a terminal dimethylallyl unit in these compounds and in compound (4) which showed the same base peak. This fragment ion was absent in the more oxygenated metabolites (5) and (6).

UV spectra (Table 1) of oligosporon (1), oligosporol B (3), hydroxyoligosporon (5), and 10',11'-epoxyoligosporon (6) were all dominated by characteristic four-banded conjugated triene absorption around $280 \mathrm{~nm},{ }^{10)}$ which was absent in the dihydro-compound (4). IR spectra (Table 1) of all five compounds showed hydroxyl absorption between $3500 \sim 3700 \mathrm{~cm}^{-1}$ and a non-conjugated carbonyl stretching frequency near 1745 $\mathrm{cm}^{-1}{ }^{11)}$ In addition, compounds (1), (4), (5) and (6) showed conjugated carbonyl stretching frequencies near $1685 \mathrm{~cm}^{-111)}$ which were absent in oligosporol B (3). The close structural relationships between the five compounds were reinforced by the extensive similarities in their ${ }^{1} \mathrm{H}$ and ${ }^{13} \mathrm{C}$ NMR spectra (Tables 2 and 3).

The structure of oligosporon was determined by NMR analysis in conjunction with the data noted above. Since we concur with the structure (1) recently proposed by STADLER et al., ${ }^{7)}$ which is also based on NMR data, we summarise here only the differences in our approach. The ${ }^{1} \mathrm{H}$ NMR spectrum with' selective decoupling provided the proton multiplicities and coupling constants (Table 2), and in conjunction with $\mathrm{H}, \mathrm{H}-\mathrm{COSY}$ established the structural segments $\mathrm{C}-2 \sim \mathrm{C}-4, \mathrm{C}-1^{\prime} \sim \mathrm{C}$ $3^{\prime}, \mathrm{C}-4^{\prime} \sim \mathrm{C}-7^{\prime}$, and $\mathrm{C}-9^{\prime} \sim \mathrm{C}-12^{\prime}$ with their substituents. An APT ${ }^{13} \mathrm{C}$ spectrum defined the extent of protonation

Table 1. Physico-chemical properties of A. oligospora metabolites

\begin{tabular}{|c|c|c|c|c|c|c|c|c|}
\hline & $\begin{array}{l}\text { Oligosporon } \\
\text { (1) }\end{array}$ & \multicolumn{2}{|c|}{$\begin{array}{l}\text { 4',5'-Dihydro- } \\
\text { oligosporon } \\
(4)\end{array}$} & \multicolumn{2}{|c|}{$\begin{array}{c}\text { Hydroxy- } \\
\text { oligosporon } \\
(5)\end{array}$} & $\begin{array}{l}\text { 10,11'-Epoxy- } \\
\text { oligosporon } \\
(6)\end{array}$ & \multicolumn{2}{|c|}{$\begin{array}{c}\text { Oligosporol B } \\
\text { (3) }\end{array}$} \\
\hline Appearance & Colourless oil & \multicolumn{2}{|c|}{ Colourless oil } & \multicolumn{2}{|c|}{ Colourless oil } & Colourless oil & \multicolumn{2}{|c|}{ Colourless oil } \\
\hline $\begin{array}{l}\text { Molecular } \\
\text { formula }\end{array}$ & $\mathrm{C}_{24} \mathrm{H}_{32} \mathrm{O}_{6}$ & \multicolumn{2}{|c|}{$\mathrm{C}_{24} \mathrm{H}_{34} \mathrm{O}_{6}$} & \multicolumn{2}{|c|}{$\mathrm{C}_{24} \mathrm{H}_{32} \mathrm{O}_{7}$} & $\mathrm{C}_{24} \mathrm{H}_{32} \mathrm{O}_{7}$ & \multicolumn{2}{|c|}{$\mathrm{C}_{24} \mathrm{H}_{34} \mathrm{O}_{6}$} \\
\hline $\begin{array}{l}\text { EI-MS } \\
\text { Found }(m / z) \\
\text { Caled }(m / z)\end{array}$ & $\begin{array}{l}\mathrm{M}^{+} \\
416.2198 \\
416.2199\end{array}$ & \multicolumn{2}{|c|}{$\begin{array}{l}\mathrm{M}^{+} \\
418.2355 \\
418.2355\end{array}$} & \multicolumn{2}{|c|}{$\begin{array}{l}\mathrm{M}^{+} \\
432.2145 \\
432.2148\end{array}$} & $\begin{array}{l}\mathrm{M}^{+} \\
432.2150 \\
432.2148\end{array}$ & \multicolumn{2}{|c|}{$\begin{array}{l}\mathrm{M}^{+} \\
418.2354 \\
418.2355\end{array}$} \\
\hline $\begin{array}{l}\text { Found }(m / z) \\
\text { Calcd }(m / z)\end{array}$ & & \multicolumn{2}{|c|}{$\begin{array}{l}\mathrm{M}^{+}-\mathrm{H}_{2} \mathrm{O} \\
400.2249 \\
400.2250\end{array}$} & \multicolumn{2}{|c|}{$\begin{array}{l}\mathrm{M}^{+}-\mathrm{H}_{2} \mathrm{O} \\
414.2055 \\
414.2042\end{array}$} & $\begin{array}{l}\mathrm{M}^{+}-\mathrm{H}_{2} \mathrm{O} \\
414.2043 \\
414.2042\end{array}$ & \multicolumn{2}{|c|}{$\begin{array}{l}\mathrm{M}^{+}-\mathrm{H}_{2} \mathrm{O} \\
400.2249 \\
400.2250\end{array}$} \\
\hline $\begin{array}{l}\text { Found }(m / z) \\
\text { Calcd }(m / z)\end{array}$ & \multicolumn{3}{|l|}{$\begin{array}{l}\mathrm{C}_{5} \mathrm{Hg}_{9}^{+} \\
69.0704 \\
69.0704\end{array}$} & & & & \multicolumn{2}{|c|}{$\begin{array}{l}\mathrm{C}_{5} \mathrm{Hg}_{9}^{+} \\
69.0704 \\
69.0704\end{array}$} \\
\hline $\begin{array}{l}\text { UV (EtOH) } \\
\lambda \operatorname{nm}(\varepsilon)\end{array}$ & $\begin{array}{l}261_{\operatorname{sh}}(10260) \\
273_{\operatorname{sh}}(15740) \\
280_{\max }(18300) \\
293_{\operatorname{sh}}(14420)\end{array}$ & \multicolumn{2}{|c|}{$240_{\text {end }}(2146)$} & \multicolumn{2}{|c|}{$\begin{array}{l}261_{\mathrm{sh}}(10510) \\
273_{\mathrm{sh}}(15550) \\
280_{\max }(18340) \\
291_{\mathrm{sh}}(13820)\end{array}$} & $\begin{array}{l}260_{\operatorname{sh}}(9500) \\
271_{\operatorname{sh}}(14760) \\
280_{\max }(17620) \\
288_{\operatorname{sh}}(14040)\end{array}$ & \multicolumn{2}{|c|}{$\begin{array}{l}261_{\mathrm{sh}} \\
270_{\mathrm{sh}} \\
280_{\max } \\
290_{\mathrm{sh}}\end{array}$} \\
\hline $\begin{array}{l}\mathrm{IR}\left(\mathrm{CH}_{2} \mathrm{Cl}_{2}\right) \\
\mathrm{U}_{\max }\end{array}$ & $\begin{array}{l}3579, \\
1743,1687\end{array}$ & \multicolumn{2}{|c|}{$\begin{array}{l}3685,3593 \\
1744,1685\end{array}$} & \multicolumn{2}{|c|}{$\begin{array}{l}3685,3593 \\
1745,1686\end{array}$} & $\begin{array}{l}3579,3056 \\
1743,1687\end{array}$ & \multicolumn{2}{|l|}{$\begin{array}{l}3589 \\
1741\end{array}$} \\
\hline $\begin{array}{l}C D \\
\mathrm{~nm} \Delta \varepsilon \\
\text { (dioxane) }\end{array}$ & $\begin{array}{lc}(c .0 .03) \\
390 & 0 \\
341 & +2.40 \\
310 & +0.83 \\
290_{\text {sh }} & +1.53 \\
273_{\text {sh }} & +2.38 \\
250 & +9.11 \\
232 & 0 \\
218 & -8.90\end{array}$ & $\begin{array}{l}\text { (c. } 0 . \\
390 \\
342 \\
294\end{array}$ & $\begin{array}{l}15) \\
0 \\
+1.39 \\
+0.18\end{array}$ & $\begin{array}{l}\text { (c. } 0.03 \\
390 \\
341 \\
306 \\
293_{\text {sh }} \\
281_{\text {sh }} \\
250 \\
231 \\
224\end{array}$ & $\begin{array}{l}0 \\
03) \\
+1.91 \\
+0.45 \\
+0.95 \\
+1.37 \\
+6.35 \\
0 \\
-3.62\end{array}$ & $\begin{array}{lc}\text { (c. } 0.03) \\
390 & 0 \\
338 & +1.56 \\
308 & +0.36 \\
292_{\text {sh }} & +1.15 \\
281_{\text {sh }} & +1.60 \\
252 & +5.47 \\
232 & 0 \\
219 & -5.04\end{array}$ & $\begin{array}{l}301 \\
288_{\text {sh }} \\
280 \\
250_{\text {sh }} \\
232 \\
222\end{array}$ & $\begin{array}{c}0 \\
+0.45 \\
+0.80 \\
+0.45 \\
0 \\
-0.54\end{array}$ \\
\hline
\end{tabular}


Table 2. 1H NMR data for A. oligospora metabolites ${ }^{2}$.

\begin{tabular}{|c|c|c|c|c|c|}
\hline Proton(s) & $\begin{array}{c}\text { Oligosporon } \\
\text { (1) }\end{array}$ & $\begin{array}{c}\text { 4',5'-Dihydro- } \\
\text { oligosporon } \\
(4)\end{array}$ & $\begin{array}{l}\text { Hydroxy- } \\
\text { oligosporon } \\
\text { (5) }\end{array}$ & $\begin{array}{c}\text { 10',11'-Epoxy- } \\
\text { oligosporon } \\
(6)\end{array}$ & $\begin{array}{c}\text { Oligosporol B } \\
\text { (3) }\end{array}$ \\
\hline $1-\mathrm{H}$ & & & & & $4.33, \mathrm{~m}$ \\
\hline $3 \cdot \mathrm{H}$ & $6.71, \mathrm{dt}, 4.7,1.3$ & $6.70, \mathrm{dt}, 4.7,1.3$ & $6.71, \mathrm{dt}, 4.8,1.4$ & $6.72, \mathrm{dt}, 4.7,1.5$ & 5.77, dh $5.5,1.4$ \\
\hline $4-\mathrm{H}$ & $5.03, \mathrm{dm}, 4.7$ & $5.02, \mathrm{~m}$ & $5.03, \mathrm{dm}, 4.7$ & $5.04, \mathrm{dm}, 4.7$ & $4.68, \mathrm{~m}$ \\
\hline $6-\mathrm{H}$ & $3.29, \mathrm{~d}, 1.4$ & $3.27, \mathrm{~d}, 1.4$ & $3.29, \mathrm{~d}, 1.3$ & $3.28, \mathrm{~d}, 1.1$ & $3.26, \mathrm{dd}, 1.8,1.8$ \\
\hline$I^{\prime}-H$ & $5.17, \mathrm{~d}, 8.9$ & $5.06, \mathrm{~m}$ & $5.16, \mathrm{~d}, 9.0$ & $5.18, d, 8.9$ & $4.80, \mathrm{~d}, 8.6$ \\
\hline $2^{\prime}-\mathrm{H}$ & $5.40, \mathrm{~d}, 8.9$ & $5.19, \mathrm{dq}, 8.9,1.3$ & $5.42, \mathrm{~d}, 9.0$ & $5.42, \mathrm{~d}, 8.8$ & $5.51, \mathrm{dm}, 8.6$ \\
\hline 3'-Me & $1.89, \mathrm{~d}, 1.2$ & $1.72, \mathrm{~d}, 1.3$ & $1.89, \mathrm{~d}, 1.1$ & $1.89, \mathrm{~d}, 1.1$ & $1.87, \mathrm{~d}, 1.2$ \\
\hline 4'-H & $6.16, d, 15.4$ & & $6.16, d, 15.3$ & $6.17, d, 15.3$ & $6.18, d, 15.2$ \\
\hline $4^{\prime} \cdot \mathrm{H}_{2}$ & & $2.05, \mathrm{~m}$ & & & \\
\hline $5 '-H$ & $\begin{array}{l}6.54, \mathrm{dd}, 15.3 \\
10.9\end{array}$ & & $\begin{array}{l}6.53, \mathrm{dd}, 15.3 \\
10.9\end{array}$ & $\begin{array}{l}6.53, \mathrm{dd}, 15.3 \\
10.8\end{array}$ & $\begin{array}{l}6.50, \mathrm{dd}, 15.2 \\
10.8\end{array}$ \\
\hline $5^{\prime}-\mathrm{H}_{2}$ & & $2.11, \mathrm{~m}$ & & & \\
\hline $6:-\mathrm{H}$ & $5.90, \mathrm{dm}, 10.9$ & $5.1, \mathrm{~m}$ & $5.89, \mathrm{~d}, 11.0$ & $5.94, d, 10.8$ & $5.89, \mathrm{dm}, 10.8$ \\
\hline 7-Me & $1.82, \mathrm{~d}, 1.3$ & $1.60, \mathrm{~m}$ & $1.81, \mathrm{~d}, 1.1$ & $1.83, \mathrm{~d}, 0.8$ & $1.80, \mathrm{~d}, 1.2$ \\
\hline $8^{\prime} \cdot \mathrm{H}_{2}$ & $2.11, \mathbf{m}$ & $2.00, \mathrm{~m}$ & $2.14, \mathrm{~m}$ & $2.24, \mathrm{~m}$ & $2.1, \mathrm{~m}$ \\
\hline $9^{\prime} \cdot \mathrm{H}_{2}$ & $2.13, \mathrm{~m}$ & $2.05, \mathrm{~m}$ & $2.21, \mathrm{~m}$ & $1.69, \mathrm{~m}$ & $2.1, \mathrm{~m}$ \\
\hline $10^{\prime} \cdot \mathrm{H}$ & $5.10, \mathbf{m}$ & $5.1, \mathrm{~m}$ & $5.30, \mathrm{tm}, 7.0$ & $2.72, t, 6.3$ & $5.09, \mathrm{~m}$ \\
\hline $11^{\prime}-\mathrm{Me}$ & $1.62, d, 1.2$ & $1.62, \mathrm{~d}, 1.3$ & & $1.27 . \mathrm{s}^{\mathrm{b}}$ & $1.60, \mathrm{~d}, 1.3$ \\
\hline $11^{\prime}-\mathrm{CH}_{2} \mathrm{OH}$ & & & $4.12, \mathrm{~s}$ & & \\
\hline $12^{\prime}-\mathrm{H}_{3}$ & $1.69, \mathrm{~d}, 1.1$ & $1.68, \mathrm{~d}, 1.3$ & $1.80, \mathrm{~d}, 1.2$ & $1.31, s^{b}$ & $1.68, \mathrm{~d}, 1.2$ \\
\hline $1 "-\mathrm{H}_{\mathrm{a}}$ & $4.76, \mathrm{dt}, 14.1,1.4$ & $4.77, \mathrm{~m}$ & $4.76, \mathrm{dt}, 14.1,1.3$ & $4.77, \mathrm{dm}, 14.2$ & $4.64, \mathrm{~m}$ \\
\hline $1^{\prime \prime}-\mathrm{H}_{\mathrm{b}}$ & $4.79, \mathrm{dt}, 14.2,1.2$ & $4.77, \mathrm{~m}$ & $4.80, \mathrm{dm}, 14.2$ & $4.79, \mathrm{dm}, 14.2$ & $4.64, \mathrm{~m}$ \\
\hline $1^{\prime \prime}-\mathrm{OAC}$ & $2.09, \mathrm{~s}$ & $2.09, \mathrm{~s}$ & $2.10, \mathrm{~s}$ & $2.10, \mathrm{~s}$ & $2.09, \mathrm{~s}$ \\
\hline
\end{tabular}

a Chemical shifts $(\delta)$ with $\mathrm{CHCl}_{3}(7.27)$ as reference, multiplicities and coupling constants $(\mathrm{Hz})$ for solutions in $\mathrm{CDCl}_{3}$ at $300 \mathrm{MHz}$.

b May be interchanged.

Table 3. ${ }^{13} \mathrm{C}$ Chemical shifts for A. oligospora metabolitesa.

\begin{tabular}{|c|c|c|c|c|c|}
\hline Carbon & $\begin{array}{l}\text { Oligosporon } \\
\text { (1) }\end{array}$ & $\begin{array}{l}\text { 4',5'-Dihydro- } \\
\text { oligosporon } \\
(4)\end{array}$ & $\begin{array}{l}\text { Hydroxy- } \\
\text { oligosporon } \\
(5)\end{array}$ & $\begin{array}{c}\text { 10',11'-Epoxy- } \\
\text { oligosporon } \\
(6)\end{array}$ & $\begin{array}{l}\text { Oligosporol B } \\
\text { (3) }\end{array}$ \\
\hline 1 & 192.4 & 192.6 & 192.4 & 192.3 & 63.4 \\
\hline 2 & 131.9 & 131.8 & 131.7 & 131.9 & 132.9 \\
\hline 3 & 141.0 & 141.1 & 141.2 & 141.0 & 124.8 \\
\hline 4 & 63.9 & 63.9 & 63.8 & 64.0 & 63.4 \\
\hline 5 & 67.6 & 67.6 & 67.6 & 67.6 & 60.2 \\
\hline 6 & 57.2 & 57.2 & 57.3 & 57.2 & 57.6 \\
\hline 1 & 67.5 & 67.5 & 67.6 & 67.6 & 69.7 \\
\hline $2^{\prime}$ & 124.1 & 119.8 & 124.7 & 124.5 & 126.2 \\
\hline 3 & 140.6 & 144.0 & 140.3 & 140.4 & 139.3 \\
\hline $3^{\prime}-\mathrm{Me}$ & 13.3 & 17.0 & 13.2 & 13.3 & 13.2 \\
\hline $4^{\prime}$ & 133.2 & 39.6 & 133.8 & 133.8 & 133.8 \\
\hline $5^{\prime}$ & 127.0 & $26: 1$ & 126.6 & 126.7 & 126.1 \\
\hline 6 & 124.7 & 123.3 & 125.2 & 125.3 & 124.9 \\
\hline $7^{\prime}$ & 141.3 & 135.9 & 140.2 & 139.9 & 140.5 \\
\hline $7^{\prime}-\mathrm{Me}$ & 17.0 & 16.1 & 17.0 & 16.9 & 16.9 \\
\hline 8 & 40.1 & 39.6 & 40.1 & 36.8 & 40.1 \\
\hline $9^{\prime}$ & 26.5 & 26.6 & 26.0 & 27.3 & 26.6 \\
\hline $10^{\prime}$ & 123.7 & 124.2 & 127.7 & 63.9 & 123.8 \\
\hline $11^{\prime}$ & 131.9 & 131.4 & 134.8 & 58.5 & 131.8 \\
\hline $11^{\prime}-\mathrm{Me}$ & 17.7 & 17.7 & & $18.8^{\mathrm{b}}$ & 17.8 \\
\hline $11^{\prime}-\mathrm{CH}_{2} \mathrm{OH}$ & & & 61.6 & & \\
\hline $12^{\prime}$ & 25.7 & 25.7 & 21.3 & $24.9^{\mathrm{b}}$ & 25.7 \\
\hline $1 "$ & 60.4 & 60.4 & 60.4 & 60.3 & 65.0 \\
\hline$A c-C O$ & 170.5 & 170.5 & 170.5 & 170.4 & 171.4 \\
\hline Ac-Me & 20.9 & 20.8 & 20.8 & 20.9 & 20.9 \\
\hline
\end{tabular}

a Chemical shifts $(\delta)$ with $\mathrm{CDCl}_{3}(77.0)$ as reference for solutions in $\mathrm{CDCl}_{3}$ at $75 \mathrm{MHz}$.

b These assignments may be reversed. 
of each carbon (inherent in the assignments in Table 3), and the respective protons attached to each carbon (Table 2) were determined by HMQC spectroscopy. Extensive HMBC data summarised in Fig. 1 then provided the $\mathrm{H}, \mathrm{C}$ connectivities necessary to establish the structure (1) for oligosporon. We note in particular that strong crosspeaks arising from 3 -bond couplings between $\mathrm{H}-3$ and $\mathrm{C}-5$, and $\mathrm{H}-6$ and $\mathrm{C}-2$ of the cyclohexenone ring necessitate that the farnesyl substituent is attached to $\mathrm{C}-5$, not $\mathrm{C}-6$, of the ring. Inherent in this structure are the triene, hydroxyl, ester and enone functions observed in UV and IR spectra.

The olefinic stereochemistry of the oligosporon (1) side chain follows directly from the ${ }^{13} \mathrm{C}$ chemical shifts of the 3'-Me and 7'-Me groups in comparison with literature data for model terpenes and carotenoids. ${ }^{12)}$ The trans relative stereochemistry of the hydroxy and epoxy substituents on the cyclohexenone ring follows from comparison of the ${ }^{3} J_{3,4}$ and ${ }^{4} J_{4,6}$ values of 4.7 and $1.4 \mathrm{~Hz}$ with those for known model metabolites, assuming similar preferred conformations. Such trans systems show ${ }^{3} J_{3,4}$ and ${ }^{4} J_{4,6}$ values near 5 and $1 \mathrm{~Hz}$, while $c$ is systems show values near 2.5 and $0 \mathrm{~Hz}^{13,14)}$ Like STADLER et al., ${ }^{7)}$ we were unable to determine the relative configuration of the C-1'-hydroxyl group.

With the structure of oligosporon (1) established, the structures and depicted stereochemistry of the related metabolites (3), (4), (5) and (6) were deduced primarily from comparison of their spectroscopic data with those of oligosporon (Tables 1, 2 and 3). Structures (4) and (5) were also confirmed by extensive HMQC and HMBC NMR studies.

The dihydro-oligosporon (4) lacked the triene chromophore of oligosporon. Significant differences in its ${ }^{1} \mathrm{H}$ and ${ }^{13} \mathrm{C}$ NMR spectra relative to oligosporon were restricted to resonances arising from the C-2' $\sim \mathrm{C}-7^{\prime}$ segment of the side-chain (Tables 2 and 3), where two allylic methylene groups have replaced vicinal olefinic methine groups. It is clearly 4',5'-dihydro-oligosporon (4), a probable biogenetic precursor of oligosporon in which desaturation of the farnesyl unit has yet to occur. The olefinic stereochemistry of its side chain is again defined by the ${ }^{13} \mathrm{C}$ chemical shifts of the allylic $3^{\prime}$ - and

Fig. 1. Long range couplings $\left({ }^{1} \mathrm{H} \rightarrow{ }^{13} \mathrm{C}\right)$ observed in $\mathrm{HMBC}$ NMR spectra of oligosporon (1).

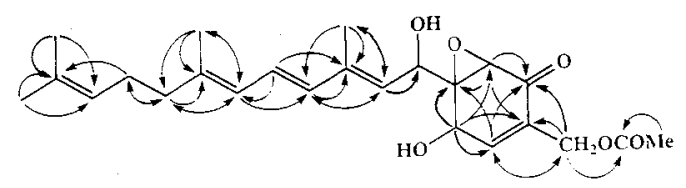

$7^{\prime}$-methyl groups. ${ }^{12,15)}$

The ${ }^{1} \mathrm{H}$ and ${ }^{13} \mathrm{C}$ NMR data for the hydroxyoligosporon (5) closely resemble those for oligosporon (1) except for the $\mathrm{C}-10^{\prime} \sim \mathrm{C}-12^{\prime}$ region of the side-chain (Tables 2 and 3 ), where one of the terminal methyl groups is now hydroxylated. In agreement, the methylene protons of this hydroxymethyl group show strong HMBC crosspeaks to the neighbouring $\mathrm{C}-10^{\prime}, \mathrm{C}-11^{\prime}$ and C-12' carbons. Literature data for such terpene systems indicate that hydroxylation of the methyl group $Z$ or $E$ to the chain leads to chemical shifts near 61.5 and $21.3 \mathrm{ppm}$, or 68.9 and $13.4 \mathrm{ppm}$, for the terminal hydroxymethyl and methyl carbons, respectively. ${ }^{15 \text { ) }}$ Comparison with the values for hydroxyoligosporon, 61.5 and $21.2 \mathrm{ppm}$, defines the structure (5) in which the $Z 11^{\prime}$-methyl substituent carries the hydroxyl group.

The structure of $10^{\prime}, 11^{\prime}$-epoxyoligosporon (6) follows directly from its ${ }^{1} \mathrm{H}$ and ${ }^{13} \mathrm{C}$ NMR spectra, which differ significantly from those of oligosporon (1) only in the resonances from the terminal isoprene unit of the sidechain (Tables 2 and 3). We are unable to comment on the relative configuration at the remote $\mathrm{C}-10^{\prime}$ centre in this metabolite.

Oligosporol B (3) differed from oligosporon (1) and its other derivatives $(4 \sim 6)$ in lacking conjugated carbonyl IR absorption (see above). Furthermore, the NMR signal of the oligosporon-type $\mathrm{C}-1$ carbonyl group near $\delta 192 \mathrm{ppm}$ was replaced by the ${ }^{13} \mathrm{C}$ and ${ }^{1} \mathrm{H}$ signals of a secondary carbinol group at $\delta 63.4$ and $4.33 \mathrm{ppm}$, respectively, with concomitant changes in other resonances in the vicinity of $\mathrm{C}-1$. These data suggested the triol structure (3) for oligosporol B, which is in agreement with that proposed by STADLER et al. ${ }^{7)}$ The coupling constants ${ }^{3} J_{3,4}$ and ${ }^{4} J_{4,6}$ of 5.5 and $1.8 \mathrm{~Hz}$ for oligosporol $B$ show that the conformation of the cyclohexenone ring of oligosporon (1) is little changed on reduction of the C-1 carbonyl group. The observed ${ }^{3} J_{1,6}$ value of $1.8 \mathrm{~Hz}$ indicates, but does not necessitate, a trans relationship between the 1-hydroxyl and the epoxide group of oligosporol B (3), as suggested by STADLER et al. ${ }^{7)}$ from NOESY correlations between $1-\mathrm{H}$ and $1^{\prime \prime}-\mathrm{H}_{2}$. Literature data indicate $J$ values of $1.5 \sim 2.3 \mathrm{~Hz}$ for such trans systems. ${ }^{16)}$

Oligosporol B (3) co-elutes from chromatograms with a minor contaminant, visible in NMR spectra, which is probably the related $4^{\prime}, 5^{\prime}$-dihydro-oligosporol B (7). APT ${ }^{13} \mathrm{C}$ NMR spectra show, together with the signals of oligosporol B, additional weak signals ( $c f$. Experimental) which in chemical shift and extent of protonation closely resemble those from the $\mathrm{C}-2^{\prime} \sim \mathrm{C}-10^{\prime}$ region of the 
side-chain of $4^{\prime}, 5^{\prime}$-dihydro-oligosporon (4). Comparison of the ${ }^{13} \mathrm{C}$ data of oligosporon (1) and its dihydroderivative (4) (Table 3 ) suggests that the undetected weak signals of the remaining carbons of $4^{\prime}, 5^{\prime}$-dihydrooligosporol B (7) could coincide with those of oligosporol B.

Absolute Configuration of the Antibiotics

With the relative configuration of the ring substituents of oligosporon (1) and its co-metabolites (3 6) established, attention was directed to the absolute configuration of this group of antibiotics. 4',5'-Dihydrooligosporon (4) has a single chromophore absorbing in the accessible UV region, which gives rise to successive positive $C D$ extrema at 342 and $252 \mathrm{~nm}$ associated with $\mathrm{n} \rightarrow \pi^{*}$ and $\pi \rightarrow \pi^{*}$ transitions of the enone system (Table 1). These Cotton effects define respectively the $5 R, 6 R$ and $4 S$ configurations of the 5,6-epoxide and 4-hydroxy groups as depicted in structure (4). Thus the CD curve of $4^{\prime}, 5^{\prime}$-dihydro-oligosporon (4) parallels those of the $4 S, 5 R, 6 R$ systems of $(+)$-desoxyepiepoxydon $(\mathbf{8})^{17)}$ and $(+)$-epiepoxydon $\{(+)$-isoepoxydon $\}(9),{ }^{13,17)}$ and is the mirror image of that of $(-)-(4 R, 5 S, 6 S)$-panepoxydon $(\mathbf{1 0}) .^{13,18)}$ In contrast, $(+)$-epoxydon (11) gives rise to successive positive and negative extrema at 341 and $245 \mathrm{~nm}$ arising from $5 R, 6 R$ and $4 R$ configurations of the epoxide and hydroxy groups, respectively. ${ }^{13,19)}$ This $4 S, 5 R, 6 R$ absolute configuration of $4^{\prime}, 5^{\prime}$-dihydrooligosporon (4) is in accord with the corresponding relative configuration deduced from the $1.4 \mathrm{~Hz}$ long range coupling between 4-H and 6-H (Table 2) and discussed above for oligosporon (1) itself.

Analysis of the CD spectra of the triene-containing cyclohexenones (1), (5) and (6) is potentially complicated by the presence of overlapping chromophores and associated Cotton effects in the $250 \sim 300 \mathrm{~nm}$ region. Their CD spectra, however, resemble markedly that of 4',5'-dihydro-oligosporon (4), with strong positive extrema near 340 and $250 \mathrm{~nm}$ (Table 1). These spectra are clearly dominated by the enone chromophore, with weak additional structure between 250 and $300 \mathrm{~nm}$ reflecting the asymmetric environment of the triene. The long wavelength extrema originate solely from the $\mathrm{n} \rightarrow \pi^{*}$ transition of the enone systems, and as with 4',5'-dihydro-

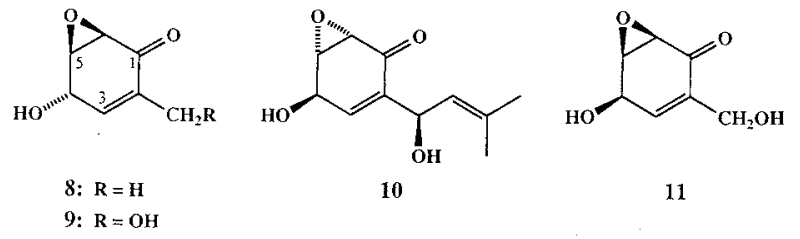

oligosporon (4) define the chirality of the epoxide groups. The short wavelength extrema are associated primarily with the $\pi \rightarrow \pi^{*}$ transition of the enone systems, and define the configuration of the 4-hydroxy groups. The resulting $4 S, 5 R, 6 R$ absolute configurations depicted for the oligosporons (1), (5) and (6) again accord with the corresponding relative configurations deduced from ring proton coupling constants (Table 2), as discussed above in the case of oligosporon (1).

Oligosporol B (3) lacks the cyclohexenone chromophore and consequent definitive CD Cotton effects (Table 1). Its ${ }^{3} J_{3,4}$ and ${ }^{4} J_{4,6}$ coupling constants (Table 2) are similar to those of the co-occurring cyclohexenones (1), (4), (5) and (6), however, suggesting the same relative and absolute configuration at C-4, C-5 and C-6. The absolute configuration of the $\mathrm{C}-1$ centre in oligosporol B (3) and its 4',5'-dihydro derivative (7) then follows from the relative configuration at this centre, as does that depicted for oligosporol A (2).

\section{Biological Activity of the Antibiotics}

The biological activity of the $A$. oligospora antibiotics against various test organisms is summarised in Table 4. MIC values for oligosporon (1) and oligosporol B (3) against the Gram-positive bacteria $B$. subtilis and $S$. aureofaciens are in the range $25 \sim 100 \mu \mathrm{g} / \mathrm{ml}$. These values from agar incorporation assays are comparable to those observed by STADLER et al.$^{7)}$ for their compounds (1), (2) and (3) in agar diffusion assays against one Gram-negative and three Gram-positive bacteria. Our dihydro- and oxidized analogues (4), (5) and (6) are less active than (1) and (3) against the Gram-positive bacteria, and all are inactive at $\leq 100 \mu \mathrm{g} / \mathrm{ml}$ against the Gramnegative plant pathogenic bacterium E. carotovora. Only oligosporon (1) and 4',5'-dihydro-oligosporon (4) inhibit vegetative growth of the plant pathogenic fungus $P$. cinnamomi at $\leq 100 \mu \mathrm{g} / \mathrm{ml}$, and none of the compounds inhibit the other plant pathogens $R$. solani and $P$. ultimum at this concentration. STADLER et $a l .{ }^{7)}$ reported no inhibition of two different filamentous fungi at $100 \mu \mathrm{g} /$ disc in agar diffusion assays.

Nematocidal activity was assessed in larval development assays ${ }^{9)}$ using the intestinal parasitic nematode Haemonchus contortus. Oligosporon (1) and 4',5'dihydro-oligosporon (4) were the most active with $\mathrm{LD}_{50}$ values of 25 and $50 \sim 100 \mu \mathrm{g} / \mathrm{ml}$, while the oxidised oligosporons (5) and (6) were inactive. STADLER et al. ${ }^{7)}$ observed no nematocidal effect for their compounds (1), (2) and (3) towards the bacterial-feeding nematode Caenorhabditis elegans at concentrations up to $100 \mu \mathrm{g} / \mathrm{ml}$. They further concluded ${ }^{20}$ that linoleic acid, obtained 
Table 4. Biological activity of A. oligospora metabolites ${ }^{\text {a }}$.

\begin{tabular}{|c|c|c|c|c|c|}
\hline Organism & $\begin{array}{l}\text { Oligosporon } \\
\text { (1) }\end{array}$ & $\begin{array}{l}\text { 4',5'-Dihydro- } \\
\text { oligosporon } \\
\text { (4) }\end{array}$ & $\begin{array}{c}\text { Hydroxy- } \\
\text { oligosporon } \\
(5)\end{array}$ & $\begin{array}{l}10,11:- \\
\text { Epoxy- } \\
\text { oligosporon } \\
(6)\end{array}$ & $\begin{array}{l}\text { Oligosporol B } \\
\text { (3) }\end{array}$ \\
\hline \multicolumn{6}{|l|}{ Bacteria (MIC) } \\
\hline $\begin{array}{l}\text { Bacillus subtilis } \\
\text { Streptomyces }\end{array}$ & 50 & 100 & 50 & 100 & 25 \\
\hline $\begin{array}{l}\text { aureofaciens } \\
\text { Erwinia carotovora }\end{array}$ & $\begin{array}{r}100 \\
>100\end{array}$ & $\begin{array}{l}>100 \\
>100\end{array}$ & $\begin{array}{l}>100 \\
>100\end{array}$ & $\begin{array}{l}>100 \\
>100\end{array}$ & $\begin{array}{c}50 \\
>100\end{array}$ \\
\hline \multicolumn{6}{|l|}{ Fungi (MIC) } \\
\hline $\begin{array}{l}\text { Phytophthora } \\
\text { cinnamomi } \\
\text { Rhizoctonia solani } \\
\text { Pythium ultimum }\end{array}$ & $\begin{array}{c}50 \\
>100 \\
>100\end{array}$ & $\begin{array}{r}100 \\
>100 \\
>100\end{array}$ & $\begin{array}{l}>100 \\
>100 \\
>100\end{array}$ & $\begin{array}{l}>100 \\
>100 \\
>100\end{array}$ & $\begin{array}{l}>100 \\
>100 \\
>100\end{array}$ \\
\hline $\begin{array}{l}\text { Nematode (LD50) } \\
\text { Haemonchus } \\
\text { contortiss }\end{array}$ & 25 & $50-100$ & inactive & inactive & $-b$ \\
\hline
\end{tabular}

from mycelial extracts, was the only detectable nematocidal agent produced by cultures of various Arthrobotrys species, including $A$. oligospora. We attribute this discrepancy between their results and our own to the different nematocidal assays employed.

\section{Conclusion}

The present work defines the structures of a group of related cyclohexene oxide metabolites from the nematode-trapping fungus $A$. oligospora, and establishes the absolute configuration of their substituted 7-oxabicyclo[4.1.0]hept-3-ene nucleus. The work independently confirms and extends recent work by STADLER et al. on $A$. oligospora metabolites. ${ }^{7)}$ The metabolites are probably of mixed biosynthetic origin, with a carbon skeleton formed by alkylation of a polyketide-derived nucleus ${ }^{13,21,22)}$ with a terpenoid-derived farnesyl unit. Members of the group display various biological activities, from nematocidal to antibacterial and antifungal. Oligosporon (1) and 4',5'-dihydro-oligosporon (4) represent only the second and most complex structural type of nematocidal metabolite to be isolated and characterised from cultures of nematophagous fungi. ${ }^{20,23)}$ They may play a rôle in the interaction between the nematophagous fungus and its nematode prey, ${ }^{1 \sim 4,23}$ ) and may also contribute to the potential ability of $A$. oligospora to protect crops and livestock from infestation by nematodes or microorganisms. 5,6 )

\section{Acknowledgements}

We thank Dr. G. R. Stirling, Plant Pathology Branch, Queensland Department of Primary Industries, Indooroopilly, Queensland, for providing the strain of $A$. oligospora used in this study, Dr. E. LACEY, McMaster Laboratory, Division of Animal Health, CSIRO, Sydney, for anthelmintic assays, and the Commonwealth Department of Industry, Technology and
Regional Development for financial support provided under the Generic Technology component of the Industry Research and Development Act 1986. We are grateful to Dr. G. R. STIRLING, Dr. P. J. DART of the Department of Agriculture of the University of Queensland, Brisbane, and Mr. R. A. DE Groot and Dr. K. D. Z. SAmuels of Incitec Ltd., Brisbane, for their interest in the project, and to Mrs. J. M. RoTHSCHILD and Mr. A. J. Herlt of this School for expert technical assistance.

\section{References}

1) Zopf, W.: Zur Kenntnis der Infektions-Krankheiten niederer Tiere und Pflanzen. Nova Acta Leopold. Carol. 52: $314 \sim 376,1888$

2) Barron, G. L.: The Nematode-Destroying Fungi. Canadian Biological Publications, Guelph, 1977

3) Nordbring-Hertz, B.: Ecology and recognition in the nematode-nematophagous fungus system. In Advances in Microbial Ecology. Vol. 10. Ed., K. C. MarshaLl, pp. $81 \sim 114$, Plenum Press, New York, 1988

4) Nordbring-Hertz, B.: Nematophagous fungi: strategies for nematode exploitation and for survival. Microbiol. Sci. 5: $108 \sim 116,1988$

5) StiRling, G. R.: Biological control of plant-parasitic nematodes. In Diseases of Nematodes. Vol. II. Eds., G. O. Poinar, Jr. \& H.-B. JANsson, pp. $93 \sim 139$, CRC Press, Boca Raton, 1988

6) WAller, P. J. \& M. FAEDo: The potential of nematophagous fungi to control the free-living stages of nematode parasites of sheep: screening studies. Vet. Parasitol. 49: 285 297, 1993

7) Stadler, M; O. Sterner \& H. Anke: New biologically active compounds from the nematode-trapping fungus Arthrobotrys oligospora Fresen. Z. Naturforsch. C 48: $843 \sim 850,1993$

8) Anderson, M. G.; T. B. JaRman \& R. W. Rickards: Antimicrobial antibiotics from the nematode trapping fungus Arthrobotrys oligospora. Abstracts, Royal Australian Chemical Institute Division of Organic Chemistry Fourteenth National Conference, No. P2, Wollongong, 1994 
9) Lacey, E.; J. M. Redwin, J. H. Gill, V. M. Demargheriti \& P. J. WALler: A larval development assay for the simultaneous detection of broad spectrum anthelmintic resistance. In Resistance of Parasites to Antiparasitic Drugs. Eds., J. C. Boray, P. J. MarTin \& R. T. Roush, pp. $177 \sim 184$, MSD AGVET, Rahway, 1990

10) ScotT, A. I.: Interpretation of the Ultraviolet Spectra of Natural Products. pp. 52 54, Pergamon Press, Oxford, 1964

11) Bellamy, L. J.: The infra-red spectra of complex molecules. pp. $46 \sim 47$ and 154 155, Chapman and Hall, London, 1975

12) Wehrli, F. W. \& T. Nishida: The use of carbon-13 nuclear magnetic resonance spectroscopy in natural products chemistry. Fortschr. Chem. Org. Naturst. 36: $1 \sim 229,1979$

13) Sekiguchi, J. \& G. M. Gaucher: Isoepoxydon, a new metabolite of the patulin pathway in Penicillium urticae. Biochem. J. 182: 445 453, 1979

14) Higa, T.; R. K. Okuda, R. M. Severns, P. J. Scheuer, C.-H. He, X. Changfu \& J. Clardy: Unprecedented constituents of a new species of acorn worm. Tetrahedron 43: $1063 \sim 1070,1987$

15) Ghisalberti, E. L.; P. R. Jefferies \& G. M. Proudfoot: The chemistry of Eremophila spp. XV. New acyclic diterpenes from Eremophila spp. Aust. J. Chem. 34:
$1491 \sim 1499,1981$

16) Duke, R. K. \& R. W. Rickards: Stereospecific total synthesis of the cyclohexene oxide antibiotic eupenoxide. J. Org. Chem. 49: 1898 1904, 1984

17) Nagasawa, H.; A. Suzuki \& S. Tamura: Isolation and structure of $(+)$-desoxyepiepoxydon and $(+)$-epiepoxydon, phytotoxic fungal metabolites. Agric. Biol. Chem. 42: $1303 \sim 1304,1978$

18) Kis, Z.; A. Closse, H. P. Sigg, L. Hruban \& G. SNatzke: Die Struktur von Panepoxydon und verwandten Pilzmetaboliten, Helv. Chim. Acta 53: 1577 1597, 1970

19) Closse, A.; R. Mauli \& H. P. Sigg: Die Konstitution von Epoxydon. Helv. Chim. Acta 49: 204 213, 1966

20) Stadler, M.; H. Anke \& O. STERner: Linoleic acid-the nematocidal principle of several nematophagous fungi and its production in trap-forming submerged cultures. Arch. Microbiol. 160: 401 405, 1993

21) ScotT, A. I.; L. ZamiR, G. T. Phillips \& M. YalPani: The biosynthesis of patulin. Bioorg. Chem. 2: 124 139, 1973

22) NabeTa, K.; A. Ichihara \& S. Sakamura: Biosynthesis of epoxydon and related compounds by Phyllosticta sp. Agric. Biol. Chem. 39: 409 413, 1975

23) JANSSON, H.-B. \& B. NORDBRING-HerTZ: Infection events in the fungus-nematode system. In Diseases of Nematodes. Vol. II. Eds., G. O. Poinar, Jr. \& H.-B. Jansson, pp. 59 72, CRC Press, Boca Raton, 1988 